\title{
綿糸の経糸糊付についで (12)
}

梁田要林

\section{2 月号 12 月号揭載}

1. ま无がを

2. 経糸糊付の諸問題

3. 糊付系として具備すべ焦件

4. 経系糊としてどんな糊がよいか

5. 糊の試験方法化ついて

6. 澱粉について

7. 油骩比ついて

8. 增量用について

9. 防徽剂化ついて

10. 糊の調合について

11. 澱枌の膨润について

12. 糊液の濃度と粘度について

13. 綛粸比

14. 新しい糊材料について

15. 糊調合設借について

16. 糊付機珹について

17. 新しい設潇機械について

\section{7. 新しい設備, 機械について}

3. 新しい糊付機城

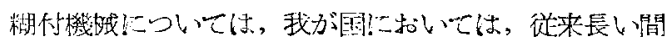
殆しど進步改善が見ら机なかったが，戦後海外の新しい

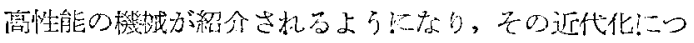

1. 積極国転送出式クリール

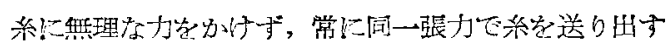
ためには，㱴極送出式が最も合理的である。

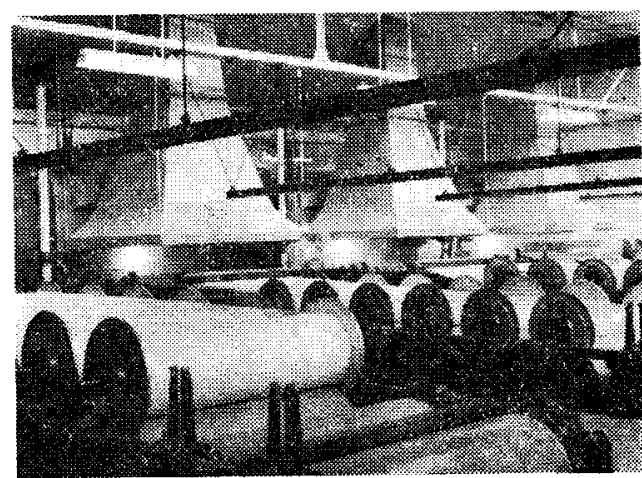

（第] 図）馬場迶業機械の積極矤出クリール

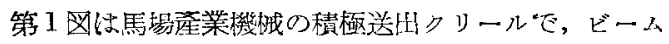
数だけのドラムをサイドシャフトで回転させてそその 上に整経ビームを載せて，各ビーム共常に同一張力にな

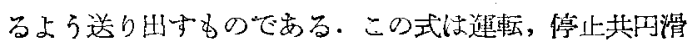

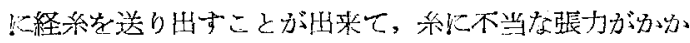
ったりたなるだりするようなことがない，文常に紋～

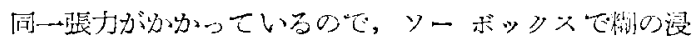

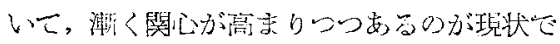 亦市。}

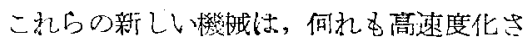

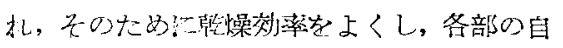

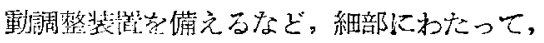

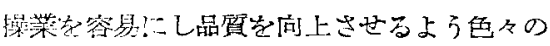
洘慮が払水扎いる。

\section{(1) $\geqslant リ ー ル$ (Creel)}

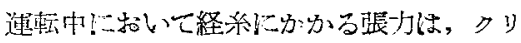
ナルの状態に影響することが大きい。高速度 化された桡械においては，整経ビームはラー ジパッケージ(ビームフランジの直膲が

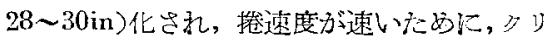

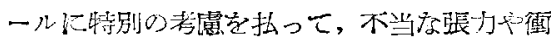

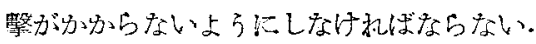

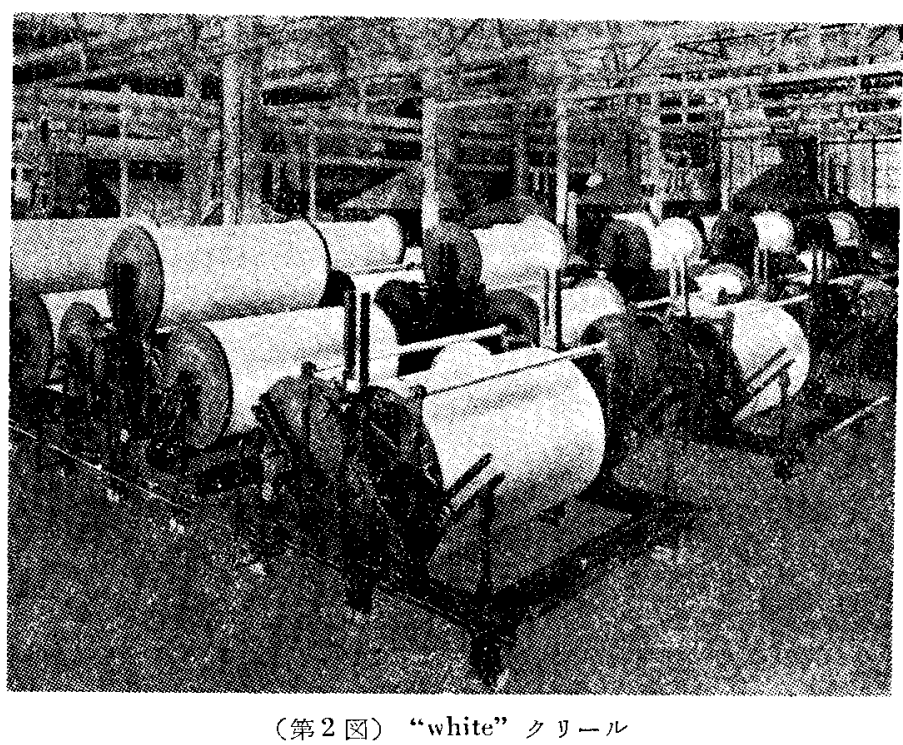

* Warp Sizing. (12)

** K. Fukada，東洋紡績線工務部織布課長 
透附羙する量す同一となり，均一な糊付が得られる、又 各ビームの張力が異なるために，揬き終り整経ビームに

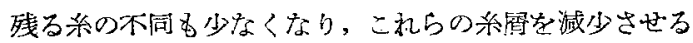
ことが出来る。

第2 図は West Point Foundry \& Machine Co., の

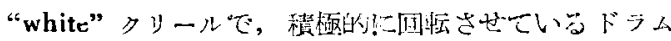
の上に 3 個のビームブ載るようにしたものて，前記のも の上り遥か、少染いドラムで目的を果すことが出来る。

\section{2. マガジンクリール (Magazine Creel)}

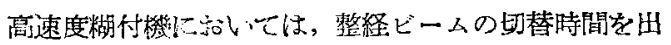
来るだけ短縮するようにしないと，機㭜の運転效率が䓕 だしく低下する.マガジンクリールは, 第 3 四に示す よろにっクリールに車翰をつけて移動出来るようにした もので，運轱中に予借クリールに整経ビームを绀掛けて おいて，速が切替出来るようにしたものである。この

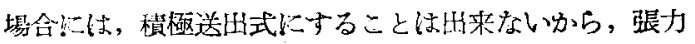
の点よついては別に考慮を払わなければならない。

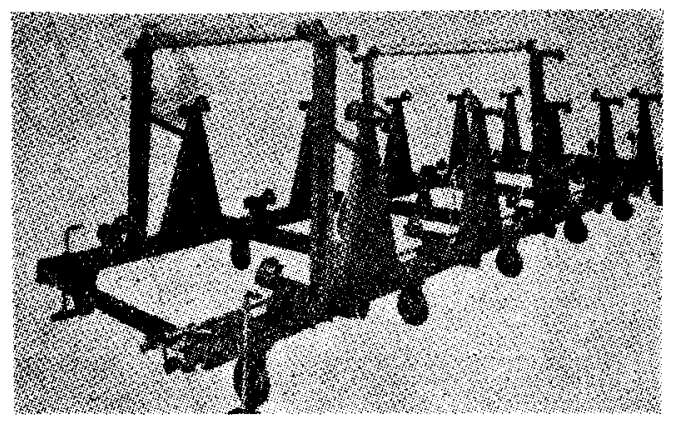

（第3 図）マガジンクリール (West Point)

3. その他のクリール

普通クリールには、ボール ベアリングを使用して， 出来るだけ軽く，同一抵抗で回るようにするのが，系に かかる張力のためにはよいがビームが回り過ぎて絃が たるむのを防ぐために、これに適当なブレーキをかける のが普通である。しかし捲速应が速くなると，この方法 ては縟張力がかかり過ぎる欠点は免れない，そのため

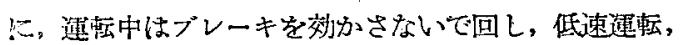
或は停転に移る時に，適当なブレーキを多けて糸のたる むのを防ぐようにした装置がある。このブレーキ調整装 置は，運枟ハンドル或心運転押ボタンと捙動されて，そ の時間的ずれ等のために，杀がたるんだり，或い澵䦔的 に不当な張力がかからないよう, 注意して設計しなけれ ばならない。

\section{(2) ドローローラ}

潄極送出クリールの埸合は別で方るが，張力!上って 糸を引出子普通のクリールでは, ソーボックス中!む

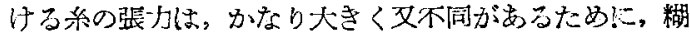

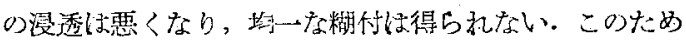

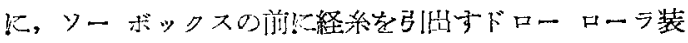

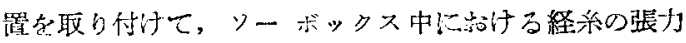

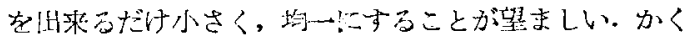
すると高速度糊付機の場合には，張力が一定になって， 経亲の做です小さくなり，糊付糸の状態はよくなって製 織性を增し、サイジンダネルの消耗等も少なくなる。

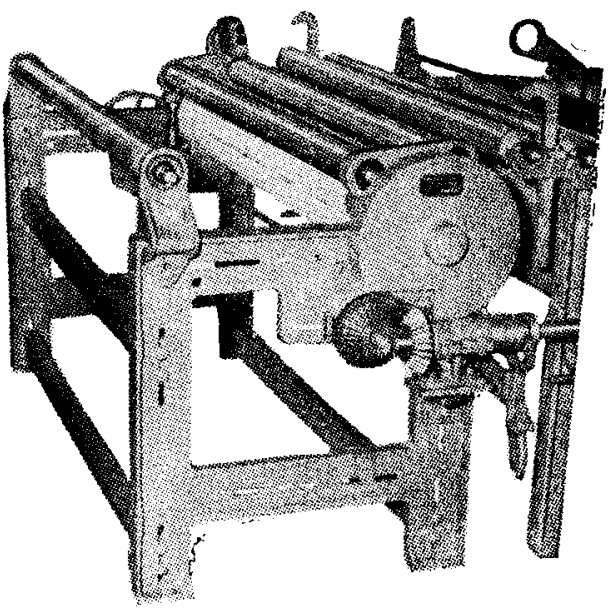

(第 4. 図)

チェンジギ+式 ドローローラ (West Point)

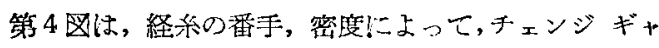
を変えて張力調整するわのであるが。第 5 园は，フリ クション装罯を使用して、フリクションディスクの代 力を適当に加淢して，張力を調整するようにした・ドロ 一ローラ装置である。

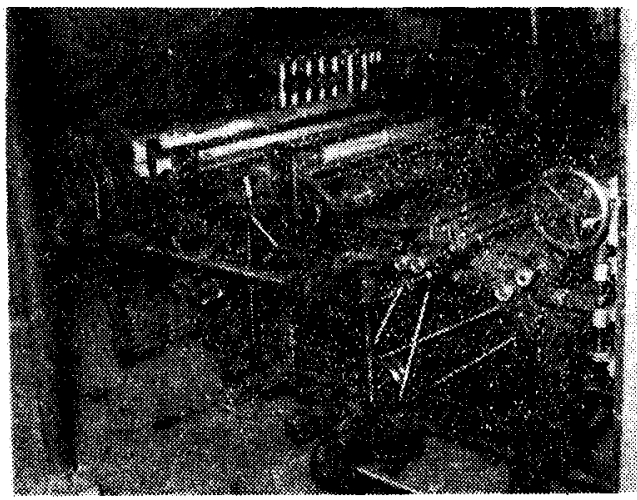

(第 5 図)

フリタション式ドローローラ(馬㳟髉業機械)

(3) ソーボックス (Sow Box)

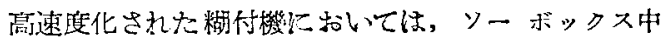
に経糸の入っている時閒が遥か儿短かくなるので，糊の 漫透附着量の点から、ソーポックスを大きくして、イマ 
ージョンッーラ，及びコッパローラを2本にするよう な方法が探ら机ている。普通はイマージョンローラを 1 本にして, ュッパローラを2本にしたるのが多く， (第6脑) Zell の機狨のように，特殊なフリューテッ ドイマージョンローラを2㤦用したるのも㚣る。

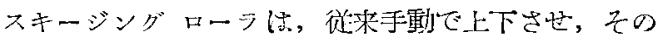

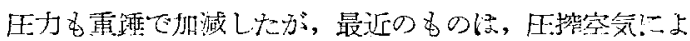
って，上下させるようにしたものが多い（第7図こ

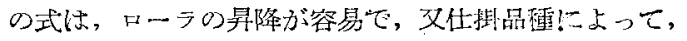

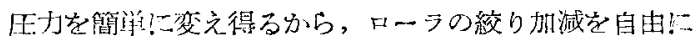
調節することが出来るので，操業上非常に便利である。

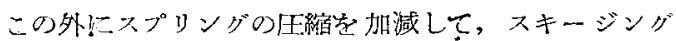
ローラの[E力調整する, Norcross Pressure Regulator

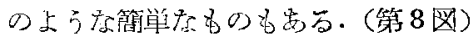

ソー ボックスに怙ける糊の煮沸装置は, 蒸気管より

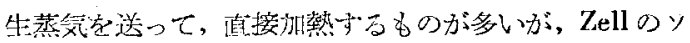
一ボックスの上らに二重底にして，閻接加熱の出承る

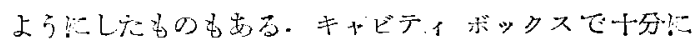

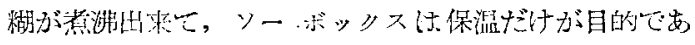
れば，加熱槽结水去使用子扎ばよいが，水の代りにグリ

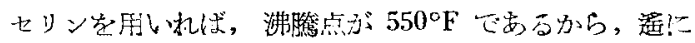
高い温度で糊を煮进することも可能でする。

こ机らソーボックス関保の材料は, 往来鋼板, 真鍮

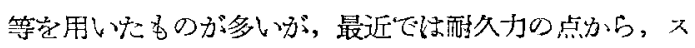
テンレススチールを使用する傾向が強い。

\section{(4) 乾燥室 (Dry Box)}

糊付機の高速度化こついて, 最も問題になるのは乾燥 能力であるが，乾燥室を大きくして途中の糸の長さを增 寸ことは，系にか次る張力や，系切れの点から好宋しく

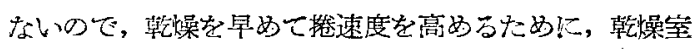
の型式，璉類は非常に多い、スラッシャに技いては，乹 蜗シリンダの数を増加したもの、ホットエアにおい

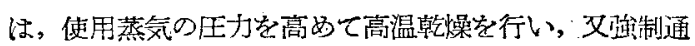
風によって，乾燥效率を高为るようにしたものが多い。

\section{Cyl-Air Slasher (West Point)}

名称の示すように, スラッシャとホットエアとを混 合した機钱で劣る。第9図に示すように，普通のスシッ シャのスモール シリンダの上部に, ラジェータとファ

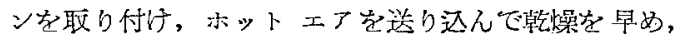
高速蓄化した糊付機で岁る・普通のスラッシャに比較し て，据扵䤄䅡も增大せず，高さも余り変化することもな

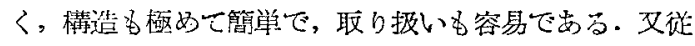
来のスラッシャを安，この方式！改造して高速度化するこ とも可能である.な抗この機諓の詳細，特徽は次の通り

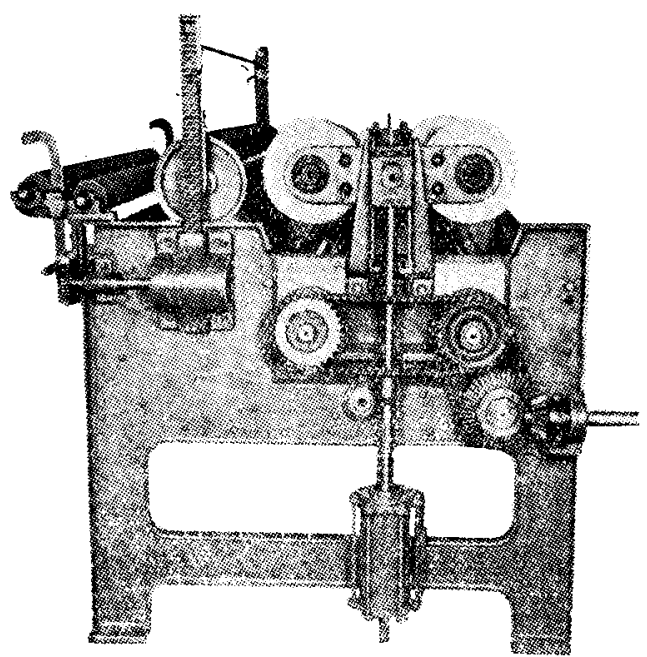

(第6図) West Pointのソーボックス
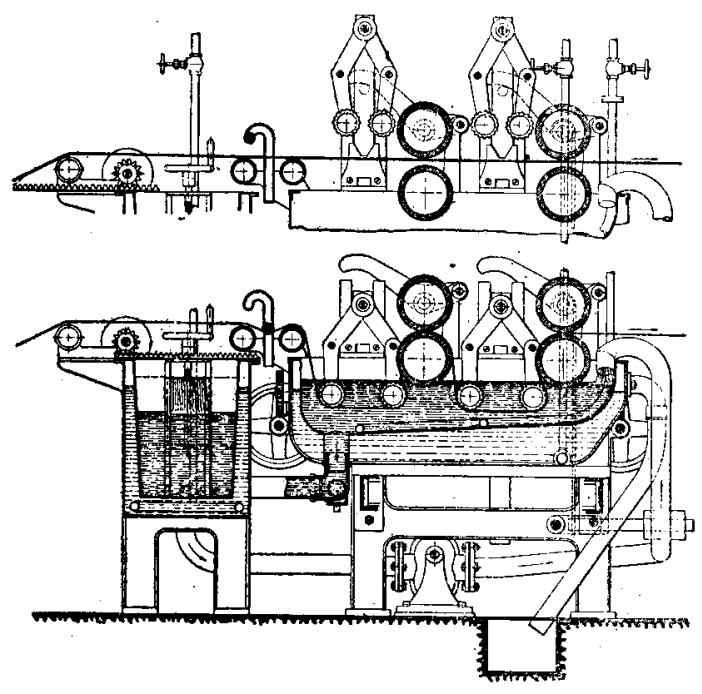

(第7図) Zell のソーボッタス

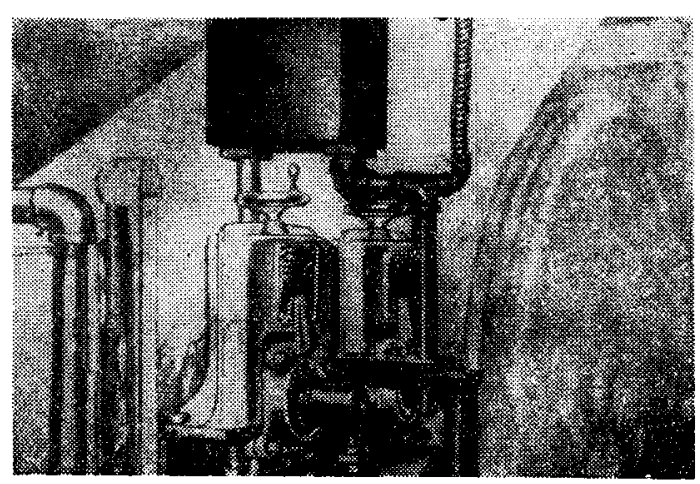

(第 8 図) Norcross Pressure Regulator 
である・

（1）ジンダは， 1560in，㨁条は 5 及び $7 \mathrm{ft}$ 使特圼力标 $22 \mathrm{lb} /$ 口" $^{\circ}$

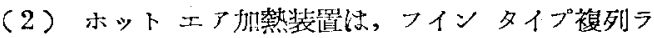
ジェー多等 3 個使用，使用压力は $100 \mathrm{lb} / \square^{\prime \prime}$ ホットエアの温度は $150^{\circ} \mathrm{C}$

ファンの渼風容量は $7500 \mathrm{cub} . \mathrm{ft} / \mathrm{min}$

(3) 乾燥能力《: $800 \mathrm{lb} / \mathrm{hr}$

搃速度怯 $60 \sim 70 \mathrm{yd} / \mathrm{min}$

（4）排気ダンパ苅適当に調整して，ホットエアの 大部分け循環されるのた，熱效来がさい。

(5) 糊付した糸が， ラージシリンダに拉触りる前

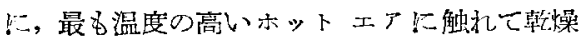
されるので, 往来のスラッシャのように，末乹 藇の糸がシリンダ表面に淔接に触れる久点が除 かれ，ホットエア糊村機の長所を有士。

2. Hi-Speed Slasher (West Point)

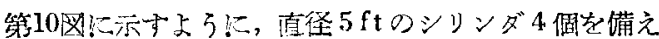

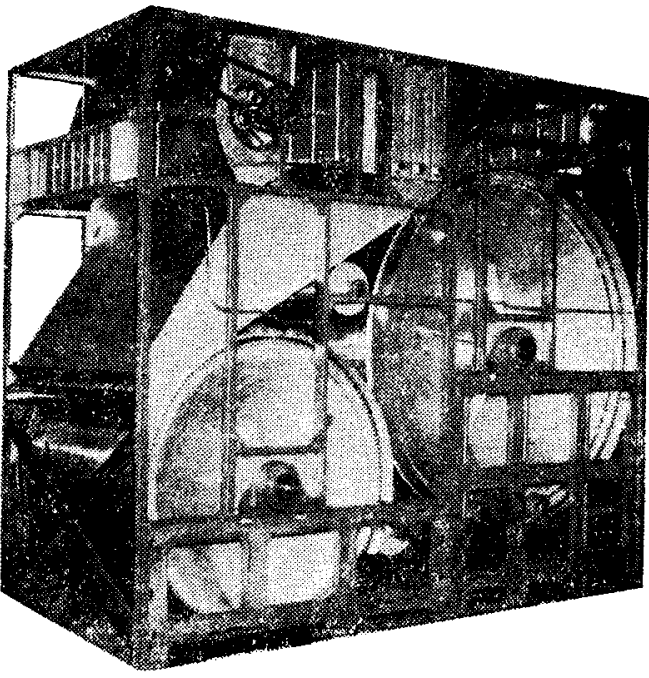

(第9应) Cyl-Air Slasher

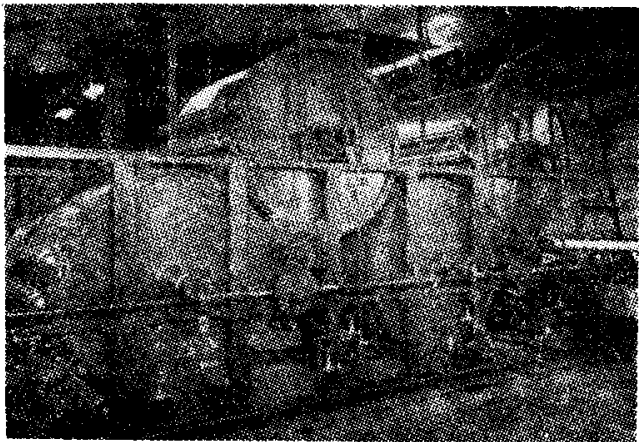

(第10府) 4-Cylinder Slasher
たスラッシャで，撩速度は $95 \mathrm{yd} / \mathrm{min}$ 乾燥能力は 1000 $\mathrm{lb} / \mathrm{hr}$ でる。各シリンダは特殊ギャ以ょって積㮌回

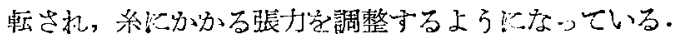
爻シリンダの表面温度は，最初に糸が触れるすのから， 順次望温になるように調整され，最高 $30 \mathrm{lb} /$ ロ までの 蒸気学使用する。

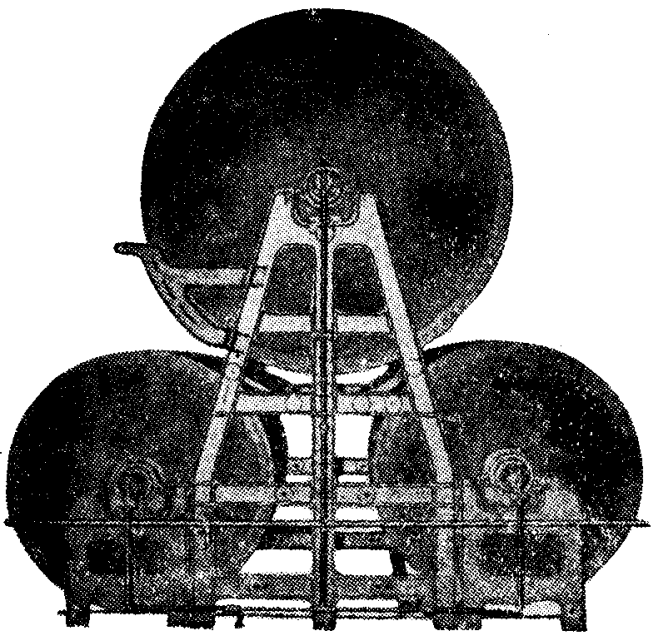

(第11国) 3-Cyl Slasher (5ft-5ft-7ft cyl)

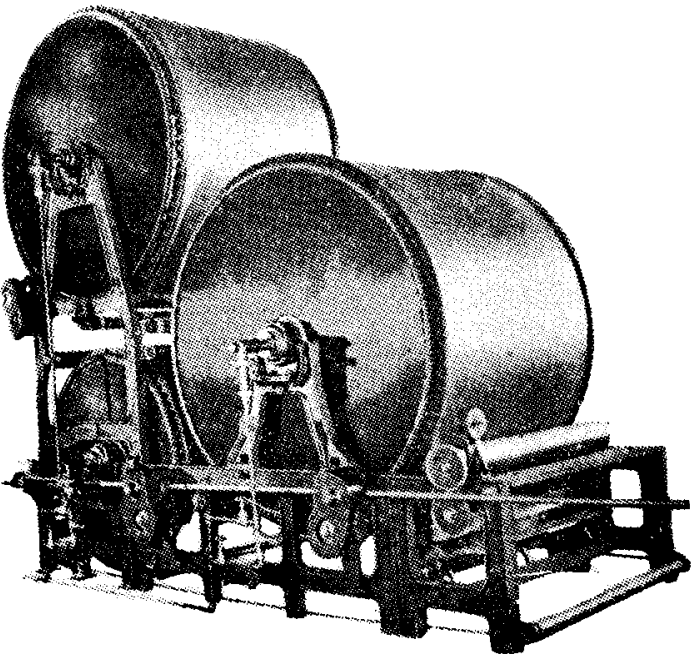

(第12図) 3-Cyl Slasher (5ft-7ft-7ft cyl)

第11，12䛜は何れむ，West Point 社の 3-Cylinder

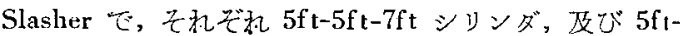
$7 \mathrm{ft}-7 \mathrm{ft}$ シリンダを有し，撩速度は $60 \sim 70 \mathrm{yd} / \mathrm{min}$ の能

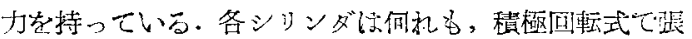

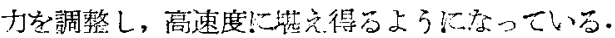

\section{3. "Gintle Air" Dryer}

Bachmann Lxbridge Worsted Corporation $\sigma$ 特部型

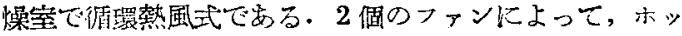


トエアを巧みに循環させて，乾燥の盛んな部分から，

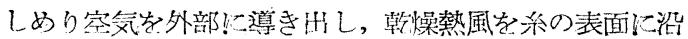
って流し, 或は糸の層の間を貫通さ好て, 蒸発速度を早 めて, 乾燥效率を高めたものである・乾燥室内にある糸

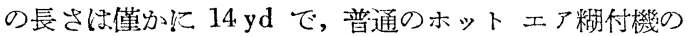
半分以下であるが，掩速度は，100 yd/min，乾燥能力は 1000 1 $200 \mathrm{lb} / \mathrm{hr}$ にも達する高性能を有している. 乾

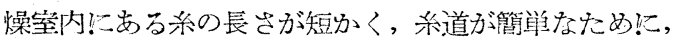
高速度!運転して子，比較的無理な長力がか次らない長 所がある・第13図は乾燥空内の内部構造とエアカレン トの状洗を説明した目面であるが，な接詳細け次の通り でする・

\section{A 型 B 型}

$\begin{array}{lll}\text { 使用蒸気の压力 } & 100 & 100 \mathrm{lb} / \mathrm{c}^{\prime \prime} \\ \text { 蒸気使用量 } & 1850 & 1530 \mathrm{lb} / \mathrm{hr} \\ \text { ファンの容量 } & 16000 & 16000 \mathrm{cub} . \mathrm{ft} / \mathrm{min} \\ \text { 排気入ァンの容量 } & 6000 & 4500 \mathrm{cub} . \mathrm{ft} / \mathrm{min} \\ \text { 乾燥能力 } & 1000 & 750 \mathrm{lb} / \mathrm{hr}\end{array}$

乾燥公の大きさ, 高 $11 \mathrm{f} \mathrm{t}-5 \mathrm{in} \quad 8 \mathrm{ft}-5 \mathrm{in}$
長 $16 \mathrm{ft}-2 \% / 8$ in $\quad 14 \mathrm{ft}-2 \%$ in

\begin{tabular}{|c|c|c|}
\hline 外壁の熱层咅度 & 47 & 47 B. T.U/sq.f t $/ \mathrm{hr}$ \\
\hline 外側の温度 & 40 & $40^{\circ} \mathrm{C}$ \\
\hline
\end{tabular}

4. 馬場式ホットエア糊付機

馬場座業機㭜の特許糊付機で，我が国で初めて出来た しか子唯一の，熱風循環式の高速度糊村機である. 往来 のスケルトンシリンダのホットエア糊村機が，ラジェ 一タが下部半分にあるため，しめり窒気が上部に上昇し て, 最後に乾燥して出てゆく糸が, 再びこのしめり空気 に触れる欠点をなくし，又自然排䒽を強制通風に代兄 て，乾燥效率を高为た機㭜である。

第14図は，乾燥室内の構造の概要を示したるのである が，スケルトンシリンダを無くして，7段のラジェー タの間に糸を通しこれらのラジェータの間を銅板で仕 町って風道学作り，系に沿って強制通風を行うものであ る・な乾燥室は上呩と下段に分けて，下段の蒸発の盛 えな部分のしめり空気を外部に取り出し，上段の乾燥し た熱風は出来るだけ循環して，熱效㻭を高めるようにし て亦る。

爻论采のホットエアでは，糊が绫け付いて糊粕付と なるため, 最初に触れるローラを外部に 取り出して，糸を邻却するの愚を行って いるが，この機械では乾燥至内けかなり 高温となるため，ぬれた糸ゔ最初触秃 るスケルトンローラを水冷式比し，温 水学送って糊が焼け村かない程罡になで 温度を下げて，糊粕付を防ぐエ夫がして ある。

このサーキュラ システム ホット エ ア糊村機は，往来の機械に比較して，遥 かに知経済になって石炭の消費量も少な く，挥速度は $60 \sim 70 \mathrm{yd} / \mathrm{min}$ まで高め ることが出来る、第15罒は外側の完圣な 保温の状沿と内部棈造を示したものであ

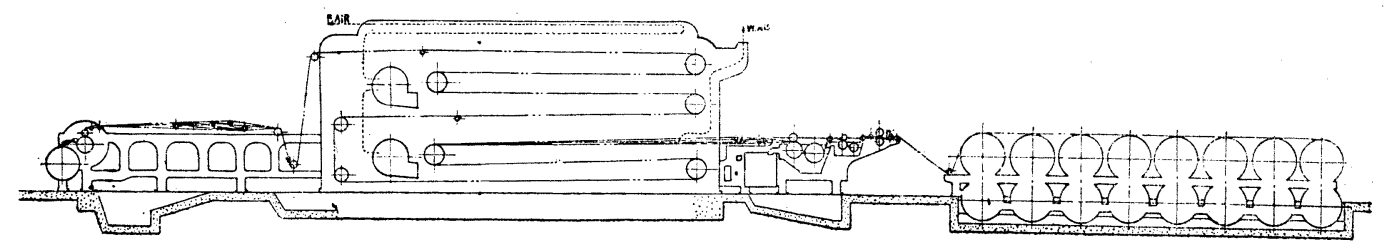

（第 14 困）馬場式ホットエア糊付機 


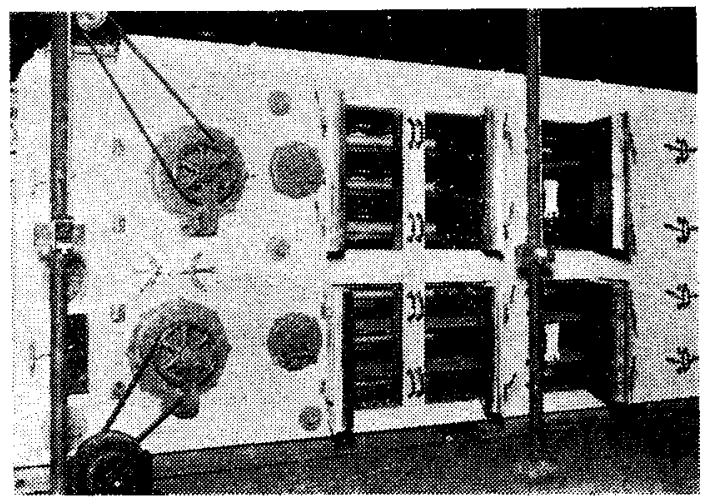

（第15図）馬場式示ット ェア糊付機外観

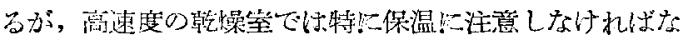
らない。

5. Perforated Drum Sizing Machine (Zell)

古くからのスルルトンシリンダのホットエア糊村機 のメーカで女る.ドイッの Zell の機械で、独特の構想 安持った料付機である。

第16四に示すように，7模の固定した Perforated

Drum（節のよ5に穴の開いたドラム）がありその外侧 と非常に軽く回る・スッルトンローラがあって，(第17 罒 紝上下交互に, スケルトンローラにかかって, 送られてゆく・こ机らのローラの上下に，6個のヒ一タ とファンがあって，上部のファンは下段のドラムに，下 部のファンは上段のドラム飞，それぞれ两側少らダクト を以て連結せられている.䘞如上部のヒ一タを通った木 ットエアが第1番目のドラムの中に送られ，又ヶルト ンシリンダにかけられた絃を通って，平均に吹き出さ れる・このホットェアは下部のフォンに 昅い込まれて再び加熱せら机，次のドう ムに送られて同じような操作が繰り返さ れる・従ってホットエアは初めは比較 的低温で後になる程高温飞なるのて，糊 村杀の乾燥の点から見れば非常に合理的 である. 熱効率も高く，蒸気の使用量か ら見ても経済的で，捏速度は $65 \mathrm{yd} / \mathrm{min}$ 位であるが，ドラムの数を堌加すれば， な抗それ以上高速度化することが师来 る.

6. 河本式温風循瞢乾燥室

ホット工了糊付譏に执いて, 排気の 持ち去る熱量の損失は案外に大きい。こ

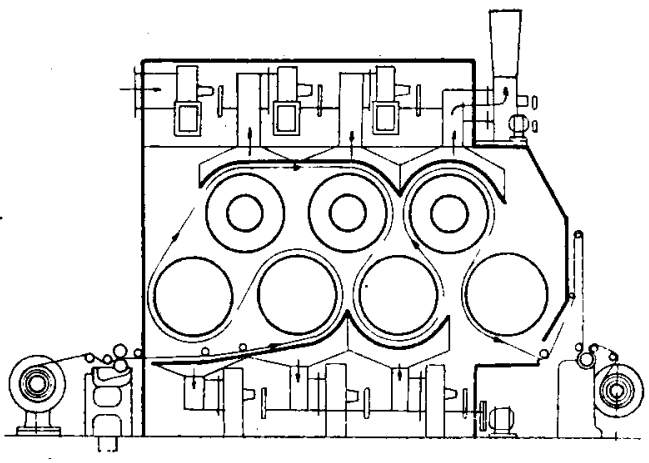

(第 16 図)

Perforated Drum Sizing Machine の內部構造

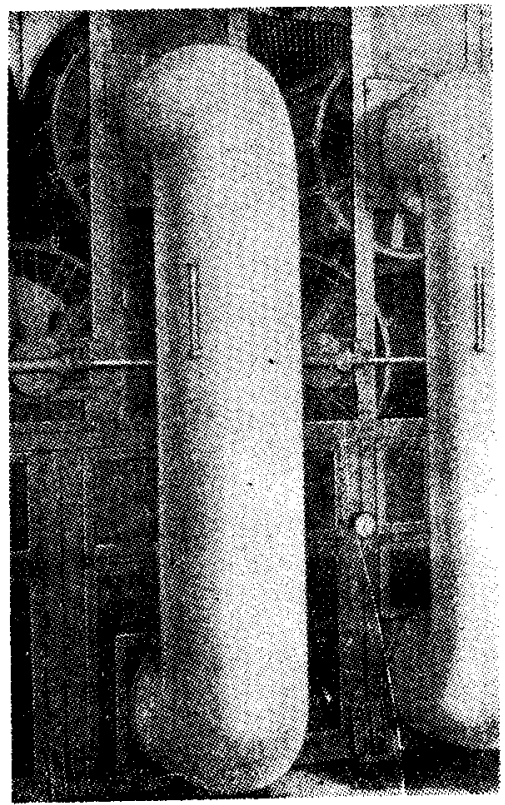

(第17図) Perforated Drum の構造

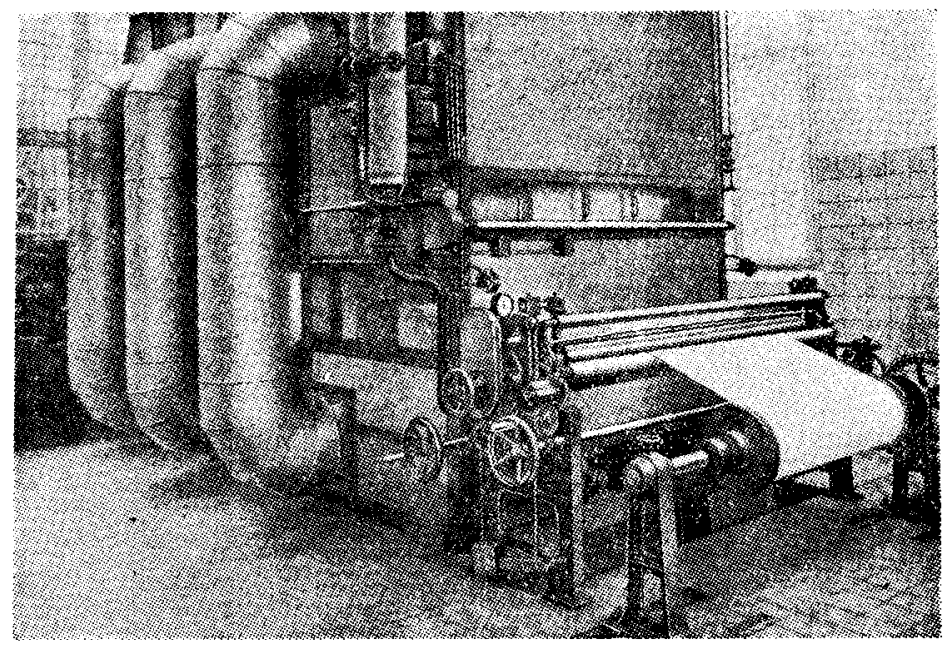

(第18図) Perforated Drum Sizing Machine 
の排气を循壊させて，その熱量を利用し熱效率を高めた ものが，第 $19 ， 20$ 区の河本製機の温風循環乾燥至です る.漧燥室の上部の方は，水蒸気を多く含えだしめり空 気が多いから，やや低位のところに 3 本のダクトを入れ て，排気の約 $80 \%$ 位のホットェアを回收し，再び加熱 して下部から 3 本のダクトで乾燥室内に放出するもので ある・これによって排気の熱量の大部分を利用すると同

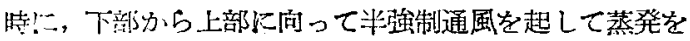

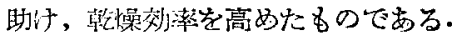

\section{（5）擭取装置}

糊付機方滈速度化するる程, 侻来のフリクション装罱に

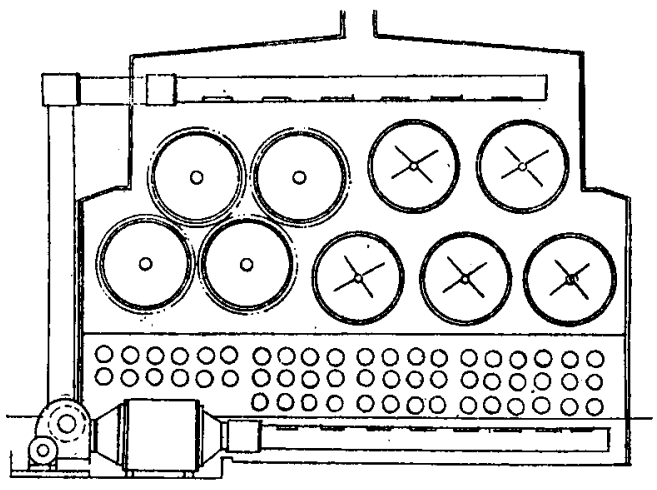

（第19図）河本式温風循環乾燥室

よる挖取方式では，正確に同一張力で撚取ること

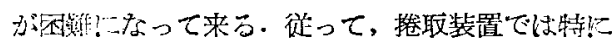
新しいテイデァによる設計は少なく，むしろ単独 モータによる挖取装置が多く使用さ絰ている。こ れは冏流モータによる制御う式で, 張力の自動嘀 整装斀の项で詳述する予定である。

\section{IT 正}

前号（12月号）54頁下段上り18行目家次の通り 訂正.

（1）最初系の当るラージシリンダの温度は 普通にして拾いて，スモールシリンダの压力

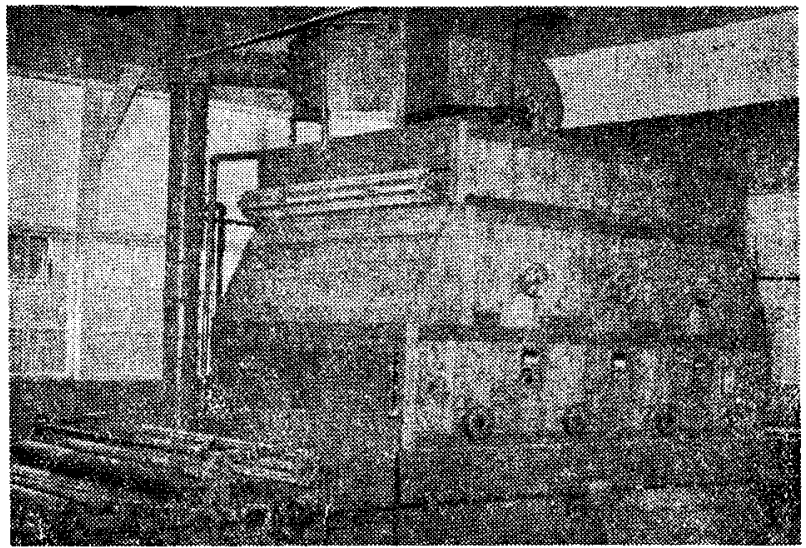

（第20図）河本式湿風循環壯置の外観

を上げて温度を高くする。

別刷 - 資料在傎表

\begin{tabular}{|c|c|c|c|}
\hline 題 & 者 & 頒 布 価 格 & $\bar{T}$ \\
\hline 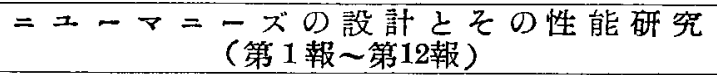 & 倉 樈 明 㸉 & $\begin{array}{llll}1 & 5 & 0 & \text { 円 }\end{array}$ & $16 \mathrm{~F}$ \\
\hline 紀 毛 カ $-r$ 表 面速度調 查表 & 紡毛接研究会 & 20 用 & 8 网 \\
\hline 綿䊉辕におけるワインダ関する調査報告 & 綃紡機研究会 & 30 网 & 8 叫 \\
\hline$\Gamma ミ ラ ン の$ 染色 & 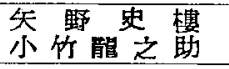 & 20 甲 & $8 \mathrm{~m}$ \\
\hline ビ = ロ ン の 混紀 交 織 & 古井充 吉 & 20 円 & $8 \mathrm{FP}$ \\
\hline 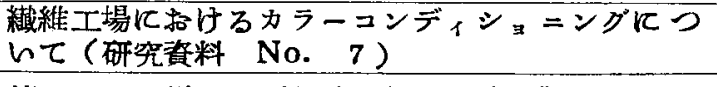 & 大島雷 義外 & $70 \mathrm{~m}$ & 8 円： \\
\hline 第 1 回 学生研究発表会講演要旨 & & $4 \quad 0 \quad P Y$ & $16 \mathrm{~m}$ \\
\hline 精紡機トップローラのスライバ把持に関する研究 & 白 樫 & 50 円 & 8 円 \\
\hline ポット精紡機の研究（第 1 報, 第 2 報) & 藤 井 澄 二外 & 40 円 & 8 月 \\
\hline 属 & 国 本 & 50 円 & 8 円 \\
\hline
\end{tabular}

